\title{
On the nucleus of Bellonci in the brain of teleost, Saivelinus malma*)
}

\author{
By \\ Naokichi Suzuki \\ (Department of Anatomy, Hiroshima University School of Medicine, Kure, Japan) \\ With six figures
}

The nucleus of Bellonci had been noticed by Bellonci (1888) and he did describe in the frog a peculiar field of very dense neuropil related it under the name of "nucleus anterior superior corporis thalami". Herrick ('17) interpreted at first the same nucleus and associated neuropil as "pars optica thalami", but in Amblystoma tigrinum he ('25) subsequently discarded his aforesaid term in the name of "neuropil of Bellonci". After that this nucleus which is a small ellipsoidal cell group in the foremost part of the thalamus has received much study in vertebrate orders including man by many investigators, such as Cairney ('26), Huber and Crosby ('26), Jansen ('29), Saito ('30), Gibert ('35), Young ('35), Ströer ('36) and Addens ('40, '43a, b, '45, '46a, b). Furthermore, Herrick ('25) who studied this nucleus in great deal in amphibians found that it is a correlation centre for olfactory, optic and some somesthetic impulses. The probably equivalent of this nucleus has been found in all major groups of vertebrates by Addens, particularly in birds, selachians and cyclostomes. Many details of the structure and connections of this nucleus, however, are still obscure as indicated by Herrick ('48). Teleosts are still wanting to a complete survey of the occurrence of the nucleus of Bellonci throughout vertebrates.

In the present paper, therefore, the structure of this nucleus in a bony fish, Saivelinus malma was communicated. For this purpose, its serial mounted transverse series of adult brains treated with the haematoxylin-eosin double dyeing were employed.

\footnotetext{
* This investigation was supported in part by a grant for scientific research from the Department of Education of the Japanese Government.

N. Suzuki
} 


\section{Abbreviations used in the figures}
com. hab
commissura habenularum
com. $p$ commissura posterior
epend. 1 . ependymal layer
fasc. retrofl.
fasciculus retroflexus
nuc. $B$. nucleus of Bellonci
nuc. B.p.d. dorsal portion of nucleus of Bellonci
nuc. B.p.v. ventral portion of nucleus of Bellonci
nuc. com. hip. nucleus commissurae hippocampi
nuc. hab. nucleus habenulae
nuc. preop. p. mag. nucleus preopticus pars magnocellularis str. med. stria medullaris
s. dors. sulcus dorsalis
s. intermed sulcus intermedius
th. dors. thalamus dorsalis
torus long. torus longitudinalis
tr. opt. tractus opticus
ventr. tert. ventriculus tertius

\section{The nucleus of Bellonci and adjacent nuclei}

In the rostral segment of the diencephalon where the unmyelinated part of the stria medullaris as it reaches the front end of the nucleus habenulae (fig. 1), a small-celled group of the nucleus commissurae hiypocampi or eminentia thalami of Bergquist" occupies the ventricular margin between the sulcus dorsalis and the sulcus intermedius. These cells are rather smaller in size than those of the nucleus habenulae which is extraordinarily well developed as indicated by Addens ('43, p. $268)^{2)}$ in cyclostomes, contrary to the description of the same author $\left({ }^{\prime} 45\right)^{3)}$ in selachians.

Coursing backward, at the level where the comissura habenularum begins to appear at the dorso-lateral summit of the habenula (fig. 2), the nucleus comissurae hippocami is generally enlarged in an ellipsoidal

1) The nucleus commissurae hippocampi:begins approximately at the same level as the ganglion habenulae and extends caudally in the stria until it turns medially to form the commissure (Addens, 146,p.97).

2) Its cells differ from those of the habenula, in that they are large and more loosely packed, while their nuclei stain fainter.

3) Like those of the nucleus of Bellonci the cells of the nucleus commissurae hippocampi are of the same size and type as the habenula cells (Addens, 143, p. 513). 


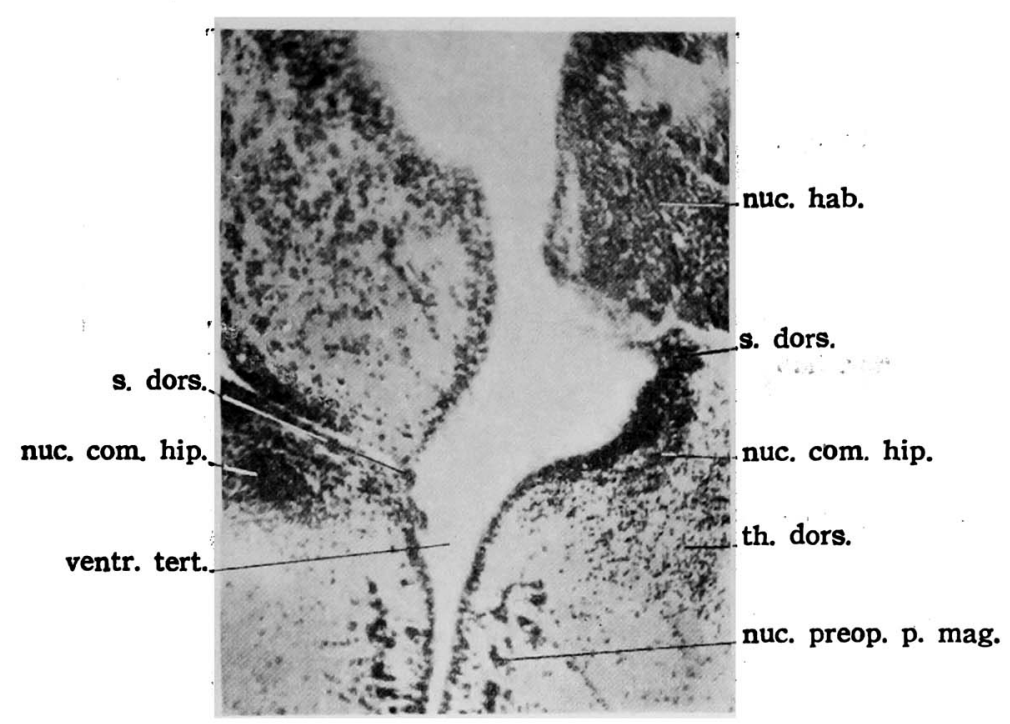

Fig. 1. Transverse section through the foremost end of the diencephalon in the brains of Saivelinus malma.

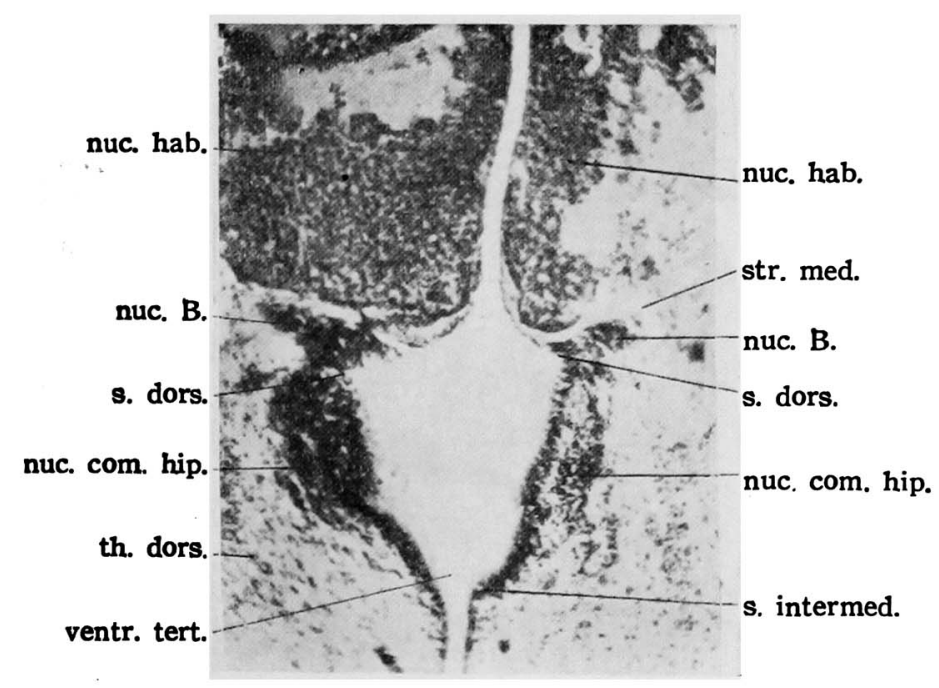

Fig. 2. Transvers section through the nucleus habenulae in the brains of Saivelinus malma. 


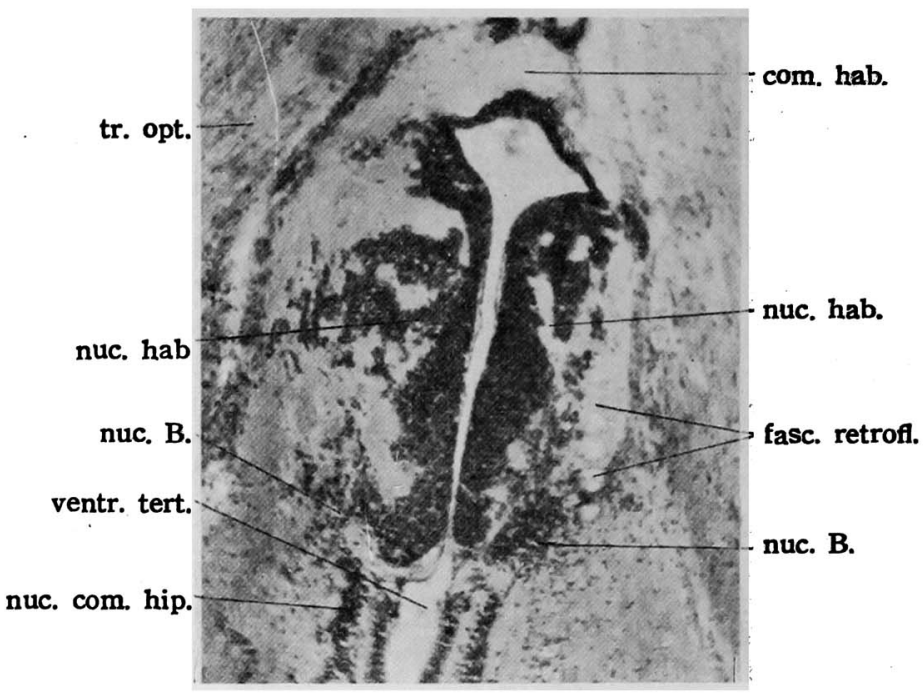

Fig. 3. Transverse section through the commissura habenularum in the brains of Saivelinus malma.

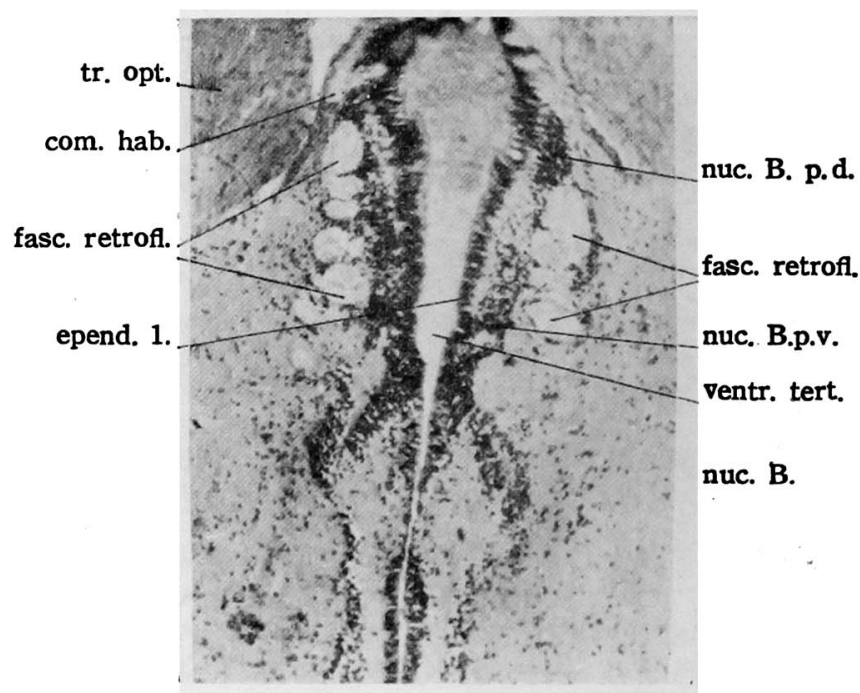

Fig. 4. Transverse section through the most caudal segment of the commissura habenularum in the brains of Saivelinus malma. 


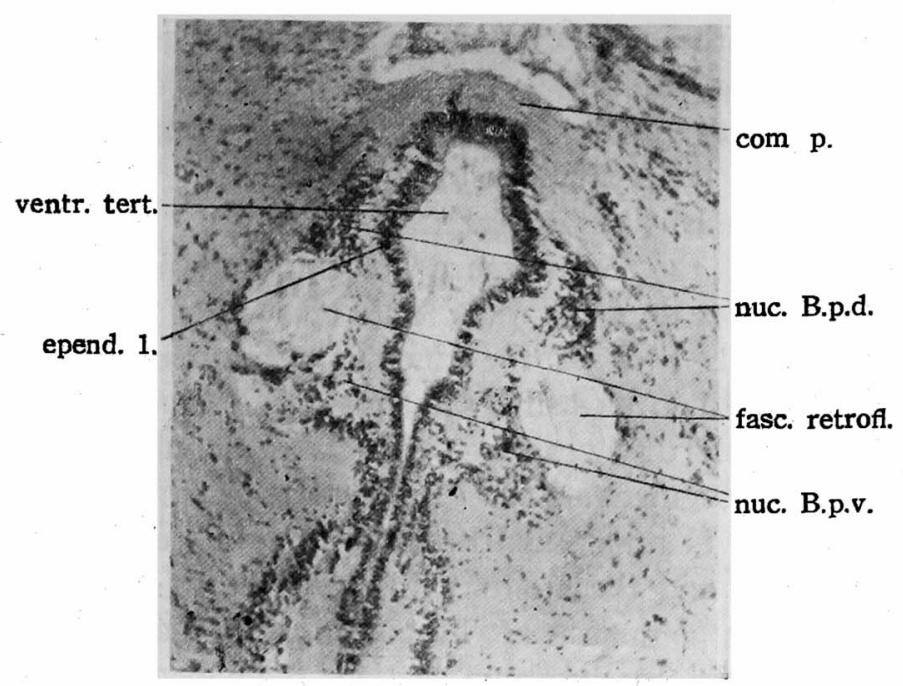

Fig. 5. Transverse section through the commissura posterior in the brains of Saivelinus malma.

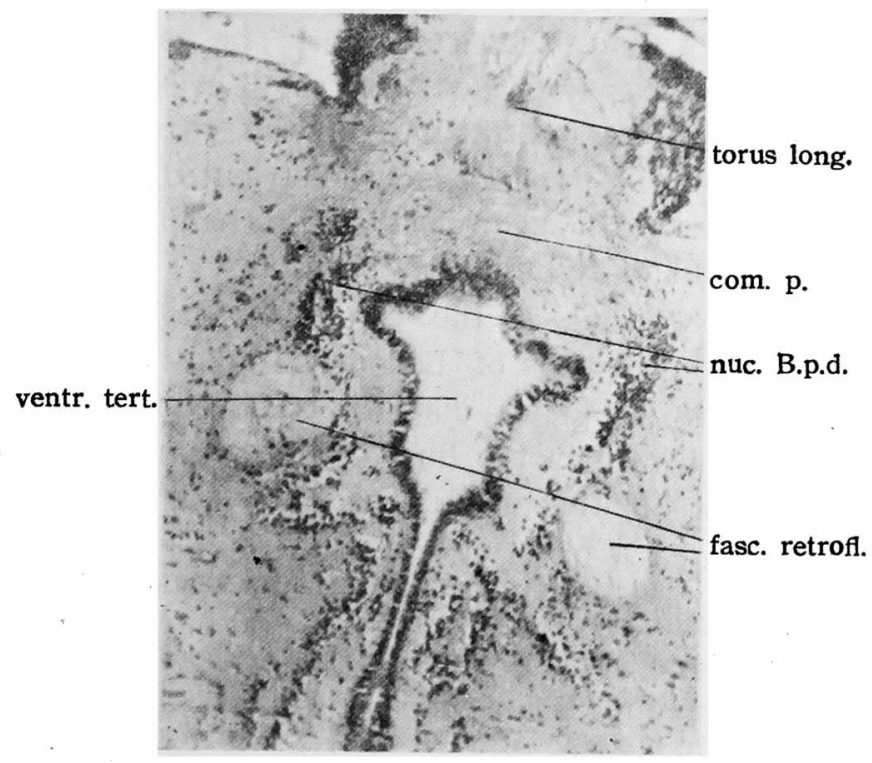

Fig. 6. Transverse scetion through the frontal segment of the torus longitudinalis in the brains of Saivelinus malma. 
cell mass and elongates vertically along the ventricular margin. In this segment, both the sulcus dorsalis and the sulcus intermedius are well remarked. In the same section immediately above the nucleus commissurae hippocampi, the other small-celled group is situated being separated from the latter nucleus by a small gap. The just aforesaid cell mass is the nucleus of Bellonci ${ }^{11}$.

At the level of the commissura habenularum(fig. 3), the nucleus of Bellonci locomotes dorso-laterally and gets near the ventro-lateral part of the habenula ${ }^{2}$, while the nucleus commissura hippocampi is considerably reduced in its cell arrangement. The cells of the nucleus of Bellonci are finely distinguished from the habenula cells.

In the caudal segment of the commissura habenularum(fig. 4), the nucleus of Bellonci is intervened between the ependymal layer of the ventricular margin and the efferent fiber path of the fasciculus retroflexus. The nucleus commissurae hippocampi is gradually reduced in its cell arrangement. In the same section, the habenula is quite disappeared.

At the foremost part of the commissura posterior (fig. 5), the cell group of the nucleus of Bellonci is separated into two, a dorsal and ventral group by the thick fiber bundle of the fasciculus retroflexus having a cell scanty space between them. The pars dorsalis of this nucleus is somewhat densely packed with small cells and a number of cells disperse beneath the ventral part of the commissura posterior, while the pars ventralis is diffusively distributed, contrary to the description of Addens ('43) ${ }^{3}$ in cyclostomes. The nucleus commissurae hippocampi is lost out of sight in this segment.

In the rostral segment of the torus longitudinalis (fig. 6), the ventral portion of the nucleus of Bellonci is quite disappeared, while the dorsal cell mass elongates dorsally and yet a number of cells infiltrate dorso-medialward in the fiber of the commissura posterior, in opposition to the designation of Addens ('46 p. 95) ${ }^{4}$. Passing further

1) This nucleus may be identical with the nucleus subhabenularis of Saito ('30, p. 215) in Entosphenus japonicus.

2) In petromyzontes, Addens ('43, p. 513) described that on the left side the habenula and nucleus of Bellonci have fused.

3) The nucleus of Bellonci is separated into two cell masses of medial and lateral being intervened by the fiber bundle of the stria medullaris (Addens, '43. p. 264, fig. 3 and 145, p 350, figs. 3 and 4).

4) In addition to the unmyelinated stria, the unpaired cell mass in the commissura habenularum, interpreted us as the fused nuclei of Bellonci is supplied by myelinated fibers (Addens, '46). 
caudad, the nucleus of Bellonci is gradually diminished in number of cells and the hindmost portion of this nucleus is indicated as a paired nucleus as shown by Addens in cyclostomes, contrary to the description of the same author $(' 45 \text { and ' } 46)^{1)}$ in selachians.

\section{Summary}

The nucleus of Bellonci and adjacent cell masses in a bony fish, Saivelinus malma, was demonstrated. The nucleus commissurae hippocampi begins to appear at the foremost dorsal and of the diencephalon in an ellipsoidal small-celled group. This nucleus is corresponded with the eminentia thalami of Bergquist. This nucleus, thereafter, elongates vertically along the ventricular margin and then gradually reduced caudalward in its cell arrangement. Slightly caudal to the beginning of this nucleus, the nucleus of Bellonci consisted of small cells lies at first immediately above the nucleus commissurae hippocampi. Coursing backward the cell mass locates dorso-laterally and comes near the ventro-lateral part of the nucleus habenulae. The size and type of cells of the nucleus commissurae hippocampi and the nucleus of Bellonci are quite similar and clearly distinguished from those of the nucleus habenulae as shown by Addens ('43) in cy. clostomes, going against the description of the same author ('46) in selachians.

With the reducement of both nuclei of the nucleus habenulae and the nucleus commissurae hippocampi, the nucleus of Bellonci elongates dorsally. At the level of the frontal segment of the commissura posterior where the aforesaid two nuclei are quite lost out of sight, the nucleus of Bellonci is intervened between the ependymal layer and the efferent fiber path of the fasciculus retroflexus. Passing further caudad, the cell mass of this nucleus is separated into two, a dorsal and ventral group by the fasciculus retroflexus, contrary to the explanation of Addens ('43) in selachians. In the level of the frontal segment of the torus longitudinalis, the ventral portion is soon after disappeared, while the dorsal portion of this nucleus enlarges dorsally and yet a few of cells infiltrate in the fibers of the commissura posterior, not in the commissura habenularum. Finally. the nucleus of Bellonci is by and by reduced in number of cells and terminate as a

1) According to the description of Addens (146, p. 94 and 145, p. 350 , figs. 3 and 4 ) the hindmostpart of the nucleus of Bellonci is an unpaired median cell mass, as the fused nuclei of Bellonci, lying in the commissure and filling it up almost entirely (figs. 3, 5, and 8). 
paired nucleus as shown by Addens ('46) in cyclostomes, in opposition to the description of the same author ('43 and '46).

Lastly it is a great pleasure to me to tender my thanks to Dr. J.L. Addens (Dutch Central Institute of Brain Research at Amsterdam) and Dr. J. Jansen (Professor of Anatomy, University of Oslo) for their kindness for sending me numerous original reprints. Grateful acknowledgment is also made to Dr. C.J. Herrick (Professor Emeritus of Neurology of the University of Chicago) for his constant advice and his kindness for sending me many precious papers and a monograph titled "The Brain of Tiger Salamander".

\section{References}

Addens, J. L. 1940 The nncleus of Bellonci in birds. Nederl. Akad. v. Wetensch. Amsterdam, Proceedings, vol. XLIII, no. 8.

1943 De kern van Bellonci en aargrezende celgroepen bij de Cyclostomen. I. Petromyzonten. Nederl. Akad. v. Wetensch. .Amsterdam, Afd. Naturkunde, vol. LII, no. 5.

1943 De kern van BelIonci en aargrenzende celgroepen bij de Cyclostomen. II. Petromyzonten (Vervolg). Myxinoiden, ibid., vol. LII, no. 8.

1945 The nucleus of Bellonci and adjacent cell groups in Selachians. I. The ganglion habenulae and its connections. Nederl. Akad. v. Wetensch. Amsterdam, Proceedings, vol. XLVIII.

1946 The nucleus of Bellonci and adjacent cell groups in selachians. II. The nucleus of Bellonci. The nucleus commissurae hippocampi (eminentia thalami). ibid., vol. XLIX.

Ariëns Kappers, C. U., Huber, G.C. and Crosby, E.C. 1936 The comparative anatomy of nervous system of vertebrates including man, Mac Millan Co. New York.

Ariëns Kappers, C.U. 1941 Neurobiotactic influences in the arangement of midbrain and 'tween-brain centres, Nederl. Akad. v. Wetensch. Amsterdam, Proceedings, vol. XLIV, no. 2.

1942 The mammalian homologues of the dorsal thalamic nuclei of reptiles, ibid., vol. XLV, no. 4.

Herrick, C.J. 1948 The brain of tiger salamander, Amblystoma tigrinum, The University of Chicago Press, Chicago, Illionis.

Hori, S. 1953 A study on the comparative anatomy of the reptilian diencephalon, Acta Anat. Niigataensia Sect. Anat. Univ. Niigataensis, vol. 30, p. 111-138.

Jansen, J. 1929 A note on the optic tract in Teleosts, Nederl. Akad. v. Wetensch. Amsterdam, Proceedings, vol. 32, no. 2.

1930 The brain of Myxine glutinosa, J. Comp. Neur., vol. 49, p. 359-507.

Kudo, K. 1923 Über den Torus longitudinalis der Knochenfische, Anat. Anz., Bd. 56, Nr. $15 / 16$.

Saito, T. 1930 Über das Gehirn des japanischer Flussneuauges (Entophenus japonicus Marteus). Fol. Anat. Jap., Bd. 8, p. 189-263.

Suzuki, N. 1936 The diencephalic and some other systems in Xantharpyia amplexicaudata, Nederl. Akad.v. Wetensch. Amsterdam, Proceedings, vol. XXXIX, no. 6.

Terui,S. 1940 on diencephalic nuclei and fiber paths in the brain of hawksbill-turtle, Eretomolchelys squamosa, Jap. J. Med. Sci., Part I. Anat., vol. VIII, no. 3. 